\title{
Evaluation of Enthalpies of Benzene- Monosubstituted Benzene Interactions by Semi-Empirical MO Calculations. Their Relationship to the Experimental Enthalpies Determined by GLPC
}

\author{
Tadashi ENDO ${ }^{\text {** }}$, Takahiro IIDA ${ }^{\mathrm{a}}$, Nobuhide FURUYA ${ }^{\mathrm{a}}$, \\ Yumiko YAMADA $^{\mathrm{b}}$ and Masato M. ITO $^{\mathrm{b}}$ \\ ${ }^{a}$ Department of Chemistry, College of Science and Engineering, \\ Aoyama Gakuin University, Chitosedai, Setagaya-ku, Tokyo 157-8572, Japan \\ ${ }^{\mathrm{b}}$ Faculty of Engineering, Soka University \\ Tangi-cho, Hachioji, Tokyo 192-8577, Japan
}

(Received: September 21, 1998 ; Accepted for publication: January 18, 1999 ; Published on Web: May 19, 1999)

Enthalpies of benzene-monosubstituted benzene interactions were evaluated by semi-empirical MO calculations of heats of formation for (i) the benzene $(\mathrm{PhH})$ dimer and (ii) benzene - monosubstituted benzene ( $\mathrm{PhX}$ ) pairs. Calculation methods, initial intermolecular distances $\left(r_{I}\right)$, and so on were investigated for the benzene dimer. The interaction enthalpy and optimized geometry calculated with PM3 were consistent with the previous experimental and theoretical results. As initial arrangements of $\mathrm{PhH}-\mathrm{PhX}$ systems, one parallel $(\mathbf{P})$ and four vertical arrangements $\left(\mathbf{V}_{r}, \mathbf{V}_{p}, \mathbf{V}_{m}\right.$, and $\mathbf{V}_{b}$ ) were chosen (Figure 1 ). In the case of $\mathbf{V}_{p}$ or $\mathbf{V}_{m}$ arrangement where the lowest $\mathrm{H}$ atom at the para or meta position to substituent $\mathrm{X}$ in $\mathrm{PhX}$ was located above the centroid of $\mathrm{PhH}$, calculated enthalpies of the interactions $\left(\Delta \Delta H_{f}\right)$ between $\mathrm{PhH}$ and $\mathrm{PhX}$ had close correlation with experimental ones $\left(\Delta \Delta H^{\mathrm{t}}\right)$ determined by gas-liquid partition chromatography (GLPC), with the correlation coefficient $(\rho)$ as large as 0.94 (Figure 5); differences between the experimental $\Delta \Delta H^{\mathrm{t}}$ values and the $\Delta \Delta H^{\mathrm{t}}$ values calculated from the correlation equation were less than ca. $0.1 \mathrm{kcal} \mathrm{mol}^{-1}$. With the other arrangements except for $\mathbf{V}_{p}$, no appreciable relationship was observed between the $\Delta \Delta H_{f}$ and $\Delta \Delta H^{\mathrm{t}}$ (Figures 2-4).

Keywords: Intermolecular interaction, Aromatic-aromatic interaction, Benzenemonosubstituted benzene, MOPAC93, Relationship between calculated and experimental interaction enthalpies 


\section{Introduction}

Precise molecular recognition is essential to living systems. For example, the following biological discrimination is well known: enzyme-substrate [1], antigen-antibody [2], nucleic acid-protein [3], drug-receptor [4], and hormone-receptor recognition [5]. In contrast, a very large number of studies have recently been made on chemical recognition mainly using various model compounds of host-guest type such as crown ethers [6], criptands [7], calixarenes [8], and convergent cleft molecules [9]. It is now accepted that molecular recognition, whether biological or chemical [10], is due to specific weak (noncovalent) interactions between interacting groups in the respective molecules.

Concerning weak interactions between groups, comparable in energies (or enthalpies) to van der Waals interactions, experimental studies have extensively been made. These include dipole - induced dipole interaction between the 1,3-dioxane and phenyl rings [11], an alkylphenyl interaction [12], an alkyl - alkyl interaction [13] including that between two $t$-butyl groups [14], and so on. In addition, recent theoretical studies on aromatic-aromatic interactions suggested an energetically favorable orientation of two aromatic rings as well as their interaction energies [15-17].

We have been studying factors controlling such precise molecular recognition as occurs in living systems, by use of a pair of acylurea derivatives [open chain analogues of pyrimidine bases (e.g., uracil and thymine)] which can associate strongly with each other as well as with themselves [18]. As a result, it has been clarified that (i) intermolecular association is the first requirement for molecular recognition [19], (ii) three-dimensional shape similarity between interacting groups in reacting molecules is responsible for more specific and precise molecular recognition than would otherwise be achieved [20].

These findings led us to investigate weak interactions between interacting groups. Using GLPC, it has been demonstrated that (i) enthalpies of weak interactions of a phenyl group $\left(\Delta \Delta H^{\mathrm{t}}\right)$ with substituted benzenes [21], alkanes [22], alkenes [23], ethers [23], and carbonyl compounds [21] range from -2.7 to $+0.1 \mathrm{kcal} \mathrm{mol}^{-1}(1 \mathrm{cal}=4.184 \mathrm{~J})$ and (ii) methylation or methoxylation of a benzene ring weakens or strengthens, respectively, the phenyl-phenyl interaction [21]. Further examinations have revealed that degree of the recognition between molecules each having a nonpolar group can be controlled by the strength of shape-specific weak interactions between nonpolar groups in the respective molecules [24].

The above-mentioned experimental enthalpies of the interactions [21] can only be determined with a phenyl group as one component, because of limitation of stationary liquids available in GLPC. Thus, some theoretical approaches to evaluate weak interactions between relatively nonpolar molecules will help to elucidate an entire picture of the weak interactions including their shape-specificity. This approach need not be very accurate and quantitative; it should, however, be (i) precise enough to bring about good correlation with experimental results and (ii) convenient enough to make it possible to calculate the interaction energies between the phenyl and a wide variety of groups within a realistic time.

$\mathrm{Ab}$ initio calculations seem not to be suitable for this purpose; they require enormous time and resources of the computer because of complicated calculations of configuration interactions (CI) using a large number of basis sets, the calculation methods being still a subject of theoretical chemists even for the intermolecular interaction of a methane dimer [25]. There appear to have been no calculation methods available for electron correlation which enable calculations of interactions between benzene and substituted benzenes to be precise enough within a 
realistic time. On the other hand, for semi-empirical methods such as PM3 in MOPAC where (i) CI calculations are not implemented explicitly and (ii) the effect corresponding to electron correlation is supposed to be incorporated implicitly in the set of adjustable parameters, the use of which is characteristic of semi-empirical calculations. This is evident from the fact that heats of formation for various organic compounds can be evaluated with considerable accuracy by means of MOPAC [26].

With this situation in mind, MOPAC was used to evaluate enthalpies of intermolecular interactions, and the effectiveness and limitations of the semi-empirical method were examined. In this paper, we wish to report that the calculated enthalpies of weak interactions between benzene and various substituted benzenes have close correlation with the corresponding experimental enthalpies determined by GLPC.

\section{Calculation methods}

All calculations were carried out with the MOPAC93 program [27] for Power Macintosh (CS MOPAC, Fujitsu Ltd.) on Apple Power Macintosh 7200/120.

As monosubstituted benzenes $(\mathrm{PhX})$, anisole (PhOMe), benzene $(\mathrm{PhH})$, chlorobenzene $(\mathrm{PhCl}), \mathrm{N}, \mathrm{N}$-dimethylaniline $\left(\mathrm{PhNMe}_{2}\right)$, ethylbenzene (PhEt), fluorobenzene (PhF), nitrobenzene $\left(\mathrm{PhNO}_{2}\right)$, and toluene (PhMe) were used.

As initial arrangements of a pair of benzene and a monosubstituted benzene $(\mathrm{PhH}-\mathrm{PhX}$ system), one parallel $(\mathbf{P})$ and four vertical arrangements $\left(\mathbf{V}_{r}, \mathbf{V}_{p}, \mathbf{V}_{m}\right.$, and $\mathbf{V}_{b}$ ) were chosen (Figure 1a). In $\mathbf{P}$ arrangement, two benzene rings of $\mathrm{PhH}$ and $\mathrm{PhX}$ molecules are stacked parallel to each other. In $\mathbf{V}_{r}$ arrangement, the lowest $\mathrm{H}$ atom of $\mathrm{PhH}$ points to the center of the benzene ring of $\mathrm{PhX}$. In $\mathbf{V}_{p}$ (Figure $1 b$ ) or $\mathbf{V}_{m}$ arrangement, the lowest $\mathrm{H}$ atom at the para or meta position, respectively, to substituent $\mathrm{X}$ is located above the centroid of $\mathrm{PhH}$. In $\mathbf{V}_{b}$ arrangement, substituent X lying at the lowest position ("bottom") of $\mathrm{PhX}$ is located above the centroid of $\mathrm{PhH}$.

In the case of $\mathbf{V}$ arrangements, an intermolecular distance is defined as the distance between the centroid of a benzene ring lying on a plane and the lowest atom $(\mathrm{H}$ or $\mathrm{X})$ of the other $\mathrm{PhH}$ or PhX molecule located above the centroid of the former benzene ring (Figure 1). With $\mathbf{P}$ arrangement, an intermolecular distance is defined as the distance between the facing "above" and "below" carbon atoms of two benzene rings of parallel orientation.

Setting up of an initial intermolecular distance $\left(r_{I}\right)$ was performed using Chem3D (CambridgeSoft Corp.) ver. 3.5 by geometrical calculation so that the $r_{I}$ may become the desired value (e.g., $2.60,2.75,3.05,3.20$, or $3.40 \AA$ ). In the case of $\mathbf{V}_{b}$ arrangement, setting up of the $r_{I}$ is shown in the caption of Figure 1.

Energy minimization (geometry optimization) was carried out in the following way both for a single molecule ( $\mathrm{PhH}$ or $\mathrm{PhX}$ ) and for a pair of molecules ( $\mathrm{PhH}-\mathrm{PhX}$ system), thereby giving their heats of formation $\left(\Delta H_{f}\right):(1)$ in the case of a single molecule, the structure preliminarily optimized by Chem3D was subject to geometry optimization with MOPAC calculation; (2) with a $\mathrm{PhH}$ - PhX system, (i) its initial arrangement (Figure 1) was set up, using the optimized structures of a $\mathrm{PhH}$ molecule and a single $\mathrm{PhX}$ one mentioned above, (ii) the $r_{I}$ was then set up, and (iii) energy minimization was performed with MOPAC calculation.

In general, enthalpy of interaction $\left(\Delta \Delta H_{f}\right)$ between $\mathrm{A}$ and $\mathrm{B}$ molecules can be defined as Eq. 1, where $\Delta H_{f}(\mathrm{~A}-\mathrm{B})$ is heat of formation of coexisting $\mathrm{A}$ and $\mathrm{B}$ molecules, $\Delta H_{f}(\mathrm{~A})$ is 


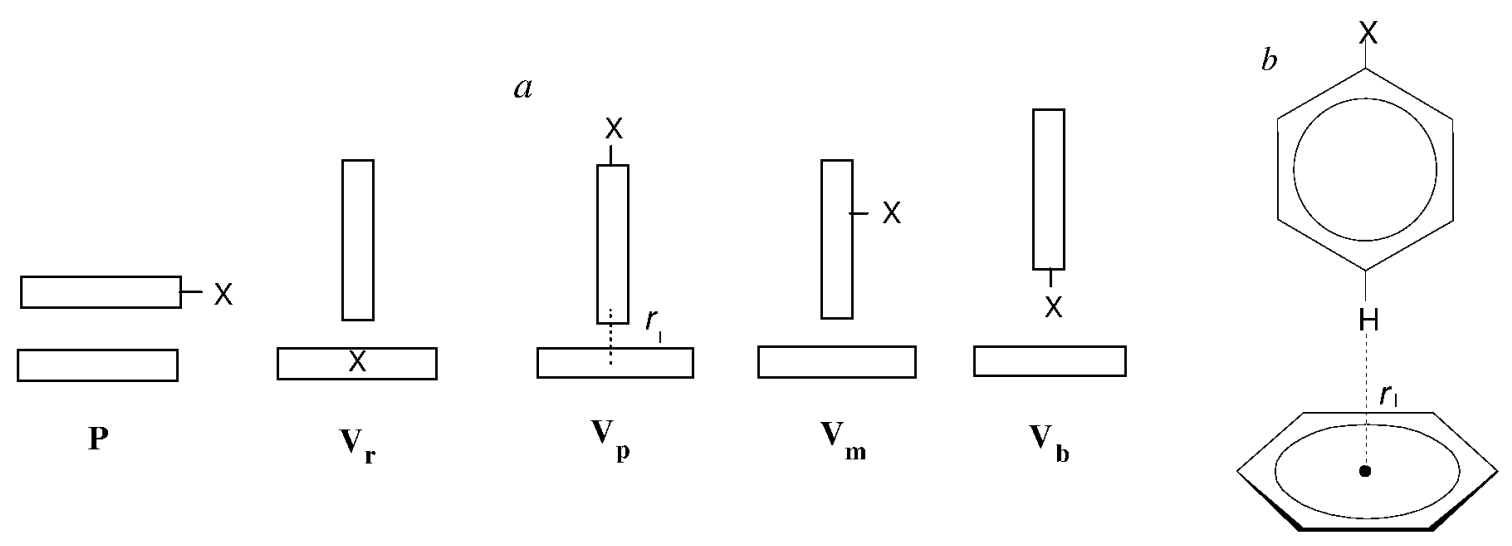

Figure 1. (a) Schematic drawings of initial arrangements $\left(\mathbf{P}, \mathbf{V}_{r}, \mathbf{V}_{p}, \mathbf{V}_{m}\right.$, and $\left.\mathbf{V}_{b}\right)$ of benzene $(\mathrm{PhH})$ - monosubstituted benzene $(\mathrm{PhX})$ systems; $(b)$ a drawing of initial arrangement $\mathbf{V}_{p}$. The symbol $r_{I}$ represents an initial intermolecular distance; for definition, see the text. The symbol $\mathrm{X}$ shows a substituent of benzene. In the case of $\mathbf{V}_{b}$ arrangement, the $r_{I}$ for $\mathrm{X}=\mathrm{Me}$, Et, $\mathrm{MeO}, \mathrm{NMe}_{2}$, or $\mathrm{NO}_{2}$ is the distance between the $\mathrm{H}$ atom in these groups (except for a $\mathrm{NO}_{2}$ group [the $\mathrm{O}$ atom instead of the $\mathrm{H}$ atom]) and the "closest" $\mathrm{C}$ atom in $\mathrm{PhH}$; for $\mathrm{X}=\mathrm{NMe}_{2}$ or $\mathrm{NO}_{2}$, the $\mathrm{N}$ atom in these two groups is located above the centroid of $\mathrm{PhH}$. In view of van der Waals radii of $\mathrm{Cl}(1.80 \AA), \mathrm{F}(1.35$ $\AA$ ), and $\mathrm{O}(1.40 \AA)$, the $r_{I}$ values set up for these are $3.50,3.05$, and $3.1 \AA$, respectively. For the other type of initial arrangement $\mathbf{V}_{r}\left(\mathbf{V}_{r} \mathbf{R}\right)$ where a $\mathrm{PhH}$ molecule located above a $\mathrm{PhX}$ molecule is rotated by $90^{\circ}$ relative to $\mathrm{PhX}$, the $\Delta \Delta H_{f}$ values are also evaluated.

that of $\mathrm{A}$

$$
\Delta \Delta H_{f}=\Delta H_{f}(\mathrm{~A}-\mathrm{B})-\Delta H_{f}(\mathrm{~A})+\Delta H_{f}(\mathrm{~B})
$$

molecule, and $\Delta H_{f}(\mathrm{~B})$ is that of $\mathrm{B}$ molecule.

\section{Results and discussion}

\section{PhH-PhH Interactions}

Evaluation of interaction enthalpies $\left(\Delta \Delta H_{f}\right)$ of benzene-benzene interaction for initial arrangement $\mathbf{V}$ was performed with three methods (MNDO, AM1, and PM3) and the results were compared with one another (Table 1). In view of the fact that (i) a half of thickness of a benzene ring is $1.7 \AA$ and (ii) van der Waals radius of an $\mathrm{H}$ atom is $1.2 \AA$, heats of formation $\left(\Delta H_{f}\right)$ were calculated, with structures optimized for various initial intermolecular distances $\left(r_{I}\right)$ of $2.60,2.75,3.05$, and $3.20 \AA$. The intermolecular distance $\left(r_{o}\right)$ optimized with PM3 method, for instance, was ca. $2.5 \AA$, irrespective of the $r_{I}$. The corresponding $\Delta H_{f} \mathrm{~s}$ for initial structure $\mathbf{V}$ were $46.53\left(r_{I}=3.20 \AA\right), 46.48(3.05 \AA), 46.35(2.75 \AA)$, and $46.29 \mathrm{kcal} \mathrm{mol}^{-1}(2.60$ $\AA$ ), whereas those for the optimized structures were all $46.26 \mathrm{kcal} \mathrm{mol}^{-1}$, regardless of the $r_{I}$. It has been clarified that (i) MNDO and AM1 methods tend to overestimate the intermolecular interactions and (ii) PM3 method is most suitable since it gives the $\Delta \Delta H_{f}$ values close to the experimental interaction enthalpy $\left(\Delta \Delta H^{\mathrm{t}}\right)$ of $-1.32 \mathrm{kcal} \mathrm{mol}^{-1}(\mathrm{X}=\mathrm{H})[28]$. 
Table 1. Effect of calculation methods on the $\Delta \Delta H_{f}$ for initial arrangements $\mathbf{V}$ and $\mathbf{P}$ of $\mathrm{PhH}-\mathrm{PhH}$ system $^{\mathrm{a}}$

\begin{tabular}{ccccc}
\hline$r_{I} / \AA$ & \multicolumn{4}{c}{$\Delta \Delta H_{f} / \mathrm{kcal} \mathrm{mol}^{-1}$} \\
\cline { 2 - 5 } & MNDO & AM1 & PM3 & PM3 \\
& $(\mathbf{V})$ & $(\mathbf{V})$ & $(\mathbf{P})$ & $(\mathbf{V})$ \\
\hline 2.60 & -4.29 & -2.96 & 0.06 & -0.52 \\
2.75 & -4.30 & -2.94 & 0.06 & -0.52 \\
3.05 & -4.29 & -2.95 & 0.06 & -0.52 \\
3.20 & -4.29 & -2.96 & 0.06 & -0.52 \\
\hline
\end{tabular}

a The following key words were chosen for PM3 method. (1) For a PhH or PhX molecule: PM3 EF XYZ PRECISE GNORM $=0.01$; (2) for a PhH-PhX system: PM3 EF XYZ PRECISE GNORM $=0.05$ LET DDMIN $=0.0$.

It is also evident from the data in Table 1 that the $\Delta \Delta H_{f}$ values by PM3 method for $\mathbf{V}$ and $\mathbf{P}$ arrangements $(\mathrm{X}=\mathrm{H})$ are -0.52 and $0.06 \mathrm{kcal} \mathrm{mol}^{-1}$, respectively, regardless of the $r_{I}$. Since the experimental interaction enthalpy $\left(\Delta \Delta H^{\mathrm{t}}\right)$ for $\mathrm{X}=\mathrm{H}$ is $-1.32 \mathrm{kcal} \mathrm{mol}^{-1}, \mathrm{~V}$ arrangement appears to be more suitable as an initial arrangement of the system than $\mathbf{P}$ arrangement.

An optimized intermolecular distance for the benzene dimer was shown to be $5.0 \AA$ between their centroids $\left(\mathrm{d}_{c b-c b}\right)$ by ab initio calculations [16, 29], molecular dynamics simulations [30], and Monte Carlo simulations [31]. In the present work, the $\mathrm{d}_{c b-c b}$ becomes $4.978 \AA$ [32], the distance practically equal to that obtained by the previous work mentioned above.

$\mathrm{Ab}$ initio calculations of the benzene dimer indicated that interplanar angles (dihedral angles) between interacting benzene molecules approaching $90^{\circ}$, the "T-stacked" arrangement, are enthalpically favorable [16]. Moreover, when they adopt edge-to-face stacked orientation [17], electrostatic interaction between two benzene rings is reported to be attractive $(-1.4 \mathrm{kcal}$ $\left.\mathrm{mol}^{-1}\right)$. These findings agree with our result that the optimized geometry, which leads to close relationship between the $\Delta \Delta H_{f}$ and $\Delta \Delta H^{\mathrm{t}}$, is similar to the initial arrangement of vertical type $(\mathbf{V})$. The T-shaped orientation of two benzene molecules is well recognized in four kinds of studies: (i) crystal structures of benzene [33], peptides (and proteins) [15], and organic compounds [34], (ii) molecular beam electric deflection studies [35], (iii) NMR studies [36], and (iv) theoretical calculations [30, 31, 37].

As to interaction energy, ab initio calculations of the benzene dimer for various orientations [16] revealed that the interaction energy minimum was ca. $-2.4 \mathrm{kcal} \mathrm{mol}^{-1}$; a similar result was obtained by more recent calculations that the interaction energy for the T-shaped structure was $-2.64 \mathrm{kcal} \mathrm{mol}^{-1}[29,38,39]$. Moreover, NMR studies showed the enthalpy $(\Delta H)$ of the benzene-benzene interaction to be ca. $-2.0 \mathrm{kcal} \mathrm{mol}^{-1}$ [40], the $\Delta H$ value corresponding to the $\Delta \Delta H^{\mathrm{t}}$ of $-1.32 \mathrm{kcal} \mathrm{mol}^{-1}$ for $\mathrm{X}=\mathrm{H}$; transfer of a benzene molecule from an environment of saturated hydrocarbon molecules into an environment of benzene molecules is energetically favorable to an extent ranging to ca. $-1 \mathrm{kcal} \mathrm{mol}^{-1}$ [41]. These theoretical and experimental results suggest the enthalpy of $\mathrm{PhH}-\mathrm{PhH}$ interaction to be ca. -1 to $-2 \mathrm{kcal} \mathrm{mol}^{-1}$. Accordingly, the calculated enthalpy $\left(\Delta \Delta H_{f}\right)$ of the $\mathrm{PhH}-\mathrm{PhH}$ interaction by $\mathrm{PM} 3$ method might be more positive by ca. $0.5 \mathrm{kcal} \mathrm{mol}^{-1}$ or more. 


\section{PhH-PhX Interactions}

As mentioned above, the calculated enthalpy $\left(\Delta \Delta H_{f}\right)$ of the $\mathrm{PhH}-\mathrm{PhH}$ interaction was satisfactory in comparison with interaction energies (or enthalpy) obtained with ab initio calculations and with the experiment. Thus, the $\Delta \Delta H_{f}$ values were further calculated for various $\mathrm{PhH}-\mathrm{PhX}$ systems in the case of the five initial arrangements. As the $r_{I}, 2.75 \AA$ was chosen, because the optimized intermolecular distance $\left(r_{o}\right)$ for $\mathrm{X}=\mathrm{H}$ has been shown to be all $2.5 \AA$ except for $\mathbf{P}$ arrangement $r_{o}=5.41 \AA$ ), regardless of the $r_{I}[42]$, and because the sum - (a half of thickness of a benzene ring) + (van der Waals radius of a $\mathrm{H}$ atom) — is $2.9 \AA$.

Figure 2 depicts a plot of the $\Delta \Delta H_{f}$ against the $\Delta \Delta H^{\mathrm{t}}$ for initial arrangement $\mathbf{P}\left(r_{I}=\right.$ $2.75 \AA$ ). Arrangements after geometry optimization (optimized geometries) have been found to resemble the initial arrangement $\mathbf{P}$. For most pairs, the $\mathrm{PhH}-\mathrm{PhX}$ interactions are slightly repulsive. Optimized intermolecular distances $\left(r_{o}\right)$ change from 4.7 to $5.5 \AA$. There exists no appreciable relationship between the $\Delta \Delta H_{f}$ and $\Delta \Delta H^{\mathrm{t}}$.

In the case of initial arrangement $\mathbf{V}_{r}\left(r_{I}=2.75 \AA\right)$, the $\mathrm{PhH}-\mathrm{PhX}$ interactions are all attractive, ranging in enthalpies markedly from -0.5 to $-5.5 \mathrm{kcal} \mathrm{mol}^{-1}$. Optimized geometries resemble initial arrangement $\mathbf{V}_{r}$ except for (i) an unreasonable vertical arrangement[VP arrangement] $(\mathrm{X}=\mathrm{Me}$ ) where two $\mathrm{H}$ atoms facing each other (an $\mathrm{H}$ atom of the methyl group in $\mathrm{PhMe}$ and an $\mathrm{H}$ atom in $\mathrm{PhH}$ ) are penetrated to each other within the van der Waals radius; (ii) an unreasonable arrangement where the two benzene rings are aligned on the same plane ("coplane") in an edge-to-edge manner, with the two closest $\mathrm{H}$ atoms in the respective ring being penetrated to each other within the van der Waals radius[CP arrangement] $(\mathrm{X}=\mathrm{Et})$; (iii) twisted $\mathrm{CP}$ — another CP-like abnormal arrangement where the two benzene rings are twisted perpendicularly to each other[CP* arrangement $](\mathrm{X}=\mathrm{F})$. Furthermore, the $r_{o}$ values alter from 1.7 to $2.5 \AA$. There is no appreciable relationship between the $\Delta \Delta H_{f}$ and $\Delta \Delta H^{\mathrm{t}}$, even if the points for the above-mentioned unreasonable arrangements are excluded.

For initial arrangement $\mathbf{V}_{b}$, the $\mathrm{PhH}-\mathrm{PhX}$ interactions are repulsive for $\mathrm{X}=\mathrm{Me}, \mathrm{F}$, and $\mathrm{NO}_{2}$, while attractive for the other Xs. Optimized geometries are similar to initial arrangement $\mathrm{V}_{b}$ except for (i) $\mathrm{X}=\mathrm{Et}$ (CP* arrangement) and (ii) $\mathrm{X}=\mathrm{OMe}$ and $\mathrm{NMe}_{2}$ (arrangements somewhat different from $\mathbf{V}_{b}$ arrangement). Moreover, the $r_{o}$ values alter greatly from 1.7 to $5.6 \AA$. The $\Delta \Delta H_{f}$ bears no appreciable relationship to the $\Delta \Delta H^{\mathrm{t}}$.

The $\Delta \Delta H_{f}$ values for initial arrangement $\mathbf{V}_{p}\left(r_{I}=2.75 \AA\right)$ are listed in Table 2 , together with the $\Delta \Delta H^{\mathrm{t}}$ values for reference. It has been clarified that (i) optimized geometries are similar to initial arrangement $\mathbf{V}_{p}$ regardless of both the $r_{I}$ and $\mathrm{X}$ and (ii) weak interactions between $\mathrm{PhH}$ and $\mathrm{PhX}$ are all attractive; the $r_{o}$ values for each system remain almost unaltered with the $r_{I}$ (ca. 2.4 to $2.5 \AA$ ). A close relationship has been found to exist between the $\Delta \Delta H_{f}$ and $\Delta \Delta H^{\mathrm{t}}$ (Figure 3), the correlation coefficient $(\rho)$ being as large as 0.94 .

In the case of initial arrangement $\mathbf{V}_{m}\left(r_{I}=2.75 \AA\right), \mathrm{PhH}-\mathrm{PhX}$ interactions are also all attractive (Table 2). Optimized geometries are all similar to initial arrangement $\mathbf{V}_{m}$. Further, the $r_{o}$ values remain almost unaltered with the systems (ca. $2.5 \AA$ ). However, the $\Delta \Delta H_{f}$ appears to have no appreciable relationship to the $\Delta \Delta H^{\mathrm{t}}$ (Figure 4).

The $\Delta \Delta H_{f}$ for the electron-donating group $\left(\mathrm{OMe}\right.$ or $\left.\mathrm{NMe}_{2}\right)$ is more negative with $\mathbf{V}_{p}$ than with $\mathbf{V}_{m}$, whereas the $\Delta \Delta H_{f}$ for the $\mathrm{NO}_{2}$ group is more negative with $\mathbf{V}_{m}$ than with $\mathbf{V}_{p}$ (Table 2). Further, the $\mathbf{V}_{p}$ and $\mathbf{V}_{m}$ arrangements are interconvertible simply by rotating the upper benzene ring in $\mathrm{PhX}$ (Figure $1 b$ ) around its $\mathrm{C}_{6}$ axis by 60 degrees. Thus each system would be able to adopt either $\mathbf{V}_{p}$ or $\mathbf{V}_{m}$ arrangement, for which the $\Delta \Delta H_{f}$ value is more negative. On this basis, of the $\Delta \Delta H_{f}$ values for the two arrangements, the more negative value was selected 
Table 2. Initial arrangements $\mathbf{V}^{\mathrm{a}}$, optimized intermolecular distances $\left(r_{o}\right)$, The $\Delta \Delta H_{f}\left(r_{I}=2.75 \AA\right)$, and the $\Delta \Delta H^{\mathrm{t}}[21]$

\begin{tabular}{|c|c|c|c|c|c|}
\hline \multirow[t]{3}{*}{$\overline{\mathrm{PhX}}$} & \multicolumn{2}{|r|}{$\mathbf{V}_{p}$} & \multicolumn{2}{|r|}{$\mathbf{V}_{m}$} & \multirow[b]{2}{*}{$\Delta \Delta H^{\mathrm{t}}$} \\
\hline & $r_{o} / \AA$ & $\Delta \Delta H_{f}$ & $r_{o} / \AA$ & $\Delta \Delta H_{f}$ & \\
\hline & & $\mathrm{kcal} \mathrm{mol}^{-1}$ & & $\mathrm{kcal} \mathrm{mol}^{-1}$ & $\mathrm{kcal} \mathrm{mol}^{-1}$ \\
\hline PhEt & 2.51 & -0.49 & 2.51 & -0.50 & $\begin{array}{l}-1.09 \\
\end{array}$ \\
\hline PhMe & 2.51 & -0.50 & 2.51 & -0.50 & -1.18 \\
\hline $\mathrm{PhF}$ & 2.48 & -0.64 & 2.48 & -0.67 & -1.26 \\
\hline $\mathrm{PhCl}$ & 2.49 & -0.61 & 2.48 & -0.63 & -1.29 \\
\hline $\mathrm{PhH}$ & 2.50 & -0.52 & 2.50 & -0.52 & -1.32 \\
\hline PhOMe & 2.45 & -0.80 & 2.50 & -0.53 & -1.51 \\
\hline $\mathrm{PhNMe}_{2}$ & 2.43 & -0.80 & 2.51 & -0.48 & -1.58 \\
\hline $\mathrm{PhNO}_{2}$ & 2.45 & -0.91 & 2.54 & -1.24 & -1.84 \\
\hline
\end{tabular}

${ }^{a}$ In the case of $\mathbf{V}_{p}$ arrangement, differences in the $r_{o}$ between the $r_{I}$ values of 2.75 and $3.05 \AA$ are all within $0.01 \AA$, and differences in the $\Delta \Delta H_{f}$ between the $r_{I}$ values of 2.75 and $3.05 \AA$ are all within $0.01 \mathrm{kcal} \mathrm{mol}^{-1}$.

for each system and plotted against the $\Delta \Delta H^{\mathrm{t}}$ values (Figure 5). A close relationship has also proved to exist between the $\Delta \Delta H_{f}$ and $\Delta \Delta H^{\mathrm{t}}$, with the $\rho$ being 0.94. In addition, the differences between the experimental $\Delta \Delta H^{\mathrm{t}}$ values and the " $\Delta \Delta H^{\mathrm{t}}$ " values calculated from the equation shown in Figure 5 have turned out to be ca. $0.1 \mathrm{kcal} \mathrm{mol}^{-1}$ or smaller.

The results described here demonstrate that it is the initial arrangement $\mathbf{V}_{p}$ or $\mathbf{V}_{m}$ that brings about close relationship between the theoretical interaction enthalpies $\left(\Delta \Delta H_{f}\right)$ and the experimental ones $\left(\Delta \Delta H^{\mathrm{t}}\right)$.

\section{Conclusion}

The present work has clarified that enthalpies of weak interactions between benzene $(\mathrm{PhH})$ and monosubstituted benzenes ( $\mathrm{PhX}$ ) can be evaluated by MOPAC93 semi-empirical MO method, the calculated enthalpies having close relationship to the experimental ones, when (i) PM3 method is used as a calculation method and (ii) the initial arrangement of the $\mathrm{PhH}-\mathrm{PhX}$ system is of the vertical type, in which the lowest $\mathrm{H}$ atom at the para or meta position to $\mathrm{X}$ in $\mathrm{PhX}$ is located above the centroid of $\mathrm{PhH}$. Further, for $\mathrm{X}=\mathrm{H}$, the optimized intermolecular distance and optimized geometry [43] are consistent with those obtained with the ab initio calculations.

Evaluation of intermolecular interactions by means of ab initio MO method requires incorporation of electron correlation, for which calculations of considerably large configuration interactions (CI) are necessary. On the other hand, in the case of MOPAC methods such as PM3, it would not be unreasonable to consider that the $\Delta \Delta H_{f}$ (a measure of weak intermolecular interactions), essentially the difference between the $\Delta H \mathrm{~s}$ (heats of formation), is expected to be evaluated nearly as precisely as the $\Delta H$ themselves. 


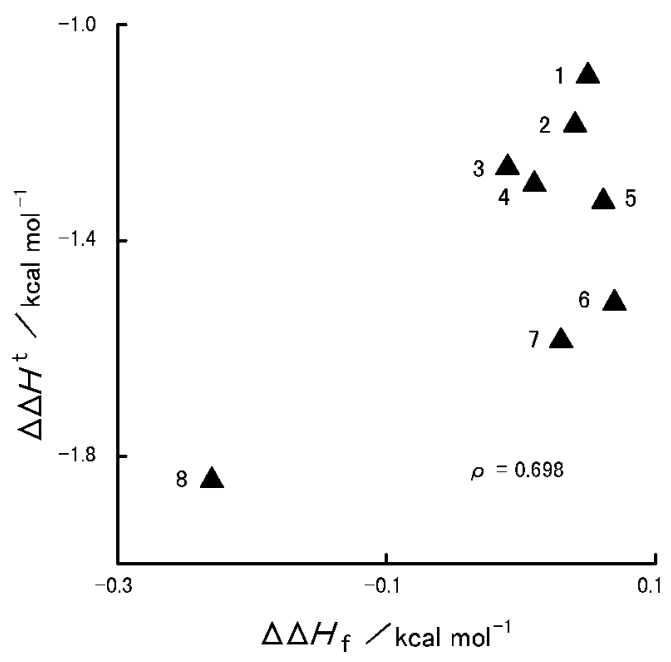

Figure 2. A plot of the $\Delta \Delta H_{f}$ optimized from initial arrangement $\mathbf{P}\left(r_{I}=2.75 \AA\right)$ against the $\Delta \Delta H^{\mathrm{t}}$. The numbers show substituents $\mathrm{X}$ of $\mathrm{PhX}$ : 1, ethyl; 2, methyl; 3, fluoro; 4, chloro; 5, H; 6, methoxy; 7, dimethylamino; 8, nitro group. All optimized geometries are similar to $\mathbf{P}$ arrangement $(\boldsymbol{\Delta})$. In the case of $r_{I}=3.40 \AA$, (1) the $\Delta \Delta H_{f}$ values are equal to those for $r_{I}=2.75 \AA$ except for (i) $\mathrm{X}=\mathrm{NMe}_{2}$ (more positive by $0.07 \mathrm{kcal}$ $\mathrm{mol}^{-1}$ ) and (ii) $\mathrm{X}=\mathrm{Et}$ (more negative by 2.07 kcal $\mathrm{mol}^{-1}$ ) and (2) optimized geometries are similar to $\mathbf{P}$ arrangement except for $\mathbf{X}=\mathrm{Et}$ (an arrangement similar to $\mathbf{V}_{r}$ ).

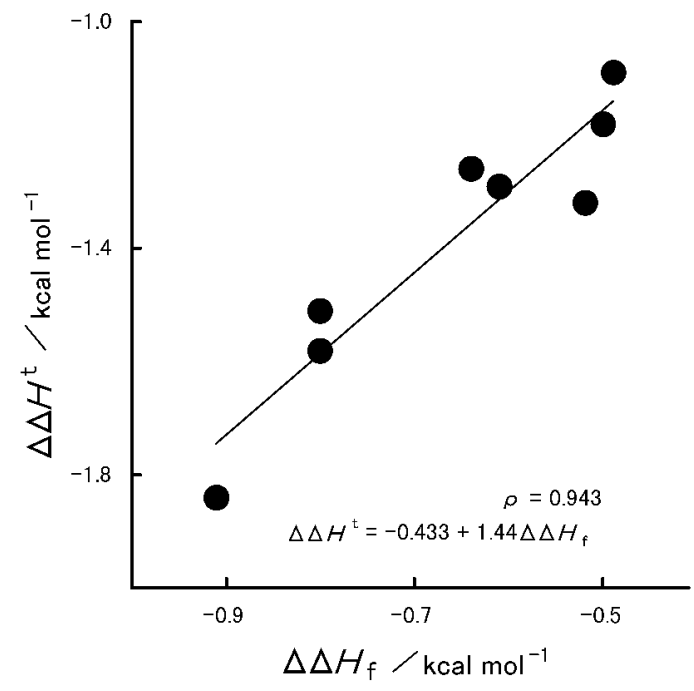

Figure 3. A plot of the $\Delta \Delta H_{f}$ optimized from initial arrangement $\mathbf{V}_{p}\left(r_{I}=2.75 \AA\right)$ against the $\Delta \Delta H^{\mathrm{t}}$. PhX molecules used are as in Figure 2. Optimized geometries are similar to $\mathbf{V}_{p}$ arrangement $(\bullet)$ except for $\mathrm{X}$ $=\mathrm{MeO}$ and $\mathrm{NMe}_{2}$ (arrangements somewhat different from $\mathbf{V}_{p}$ ).

This is the first example in which theoretical enthalpies of the weak interactions between various pairs of aromatic molecules bear close correlation with the experimental enthalpies. The results presented here encourage us to evaluate enthalpies of weak interactions between benzene and a variety of molecules such as other substituted benzenes and alkenes by semi-empirical MO methods.

We thank Mr. Mitsuru Koike for valuable assistance. 


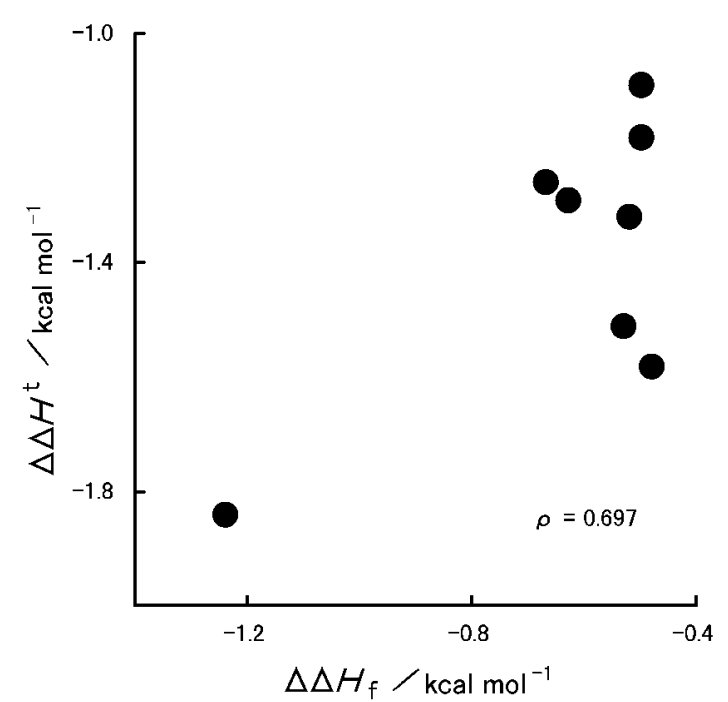

Figure 4. A plot of the $\Delta \Delta H_{f}$ optimized from initial arrangement $\mathbf{V}_{m}\left(r_{I}=2.75 \AA\right)$ against the $\Delta \Delta H^{\mathrm{t}}$. PhX molecules used are as in Figure 2. All optimized geometries are similar to $\mathbf{V}_{m}$ arrangement.

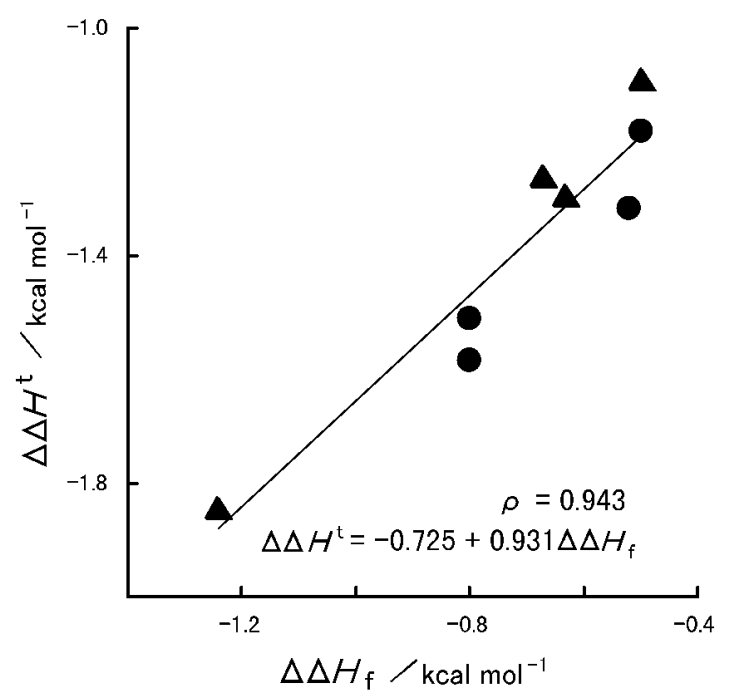

Figure 5. A plot of the $\Delta \Delta H_{f}$ optimized from initial arrangement $\mathbf{V}_{m}$ or $\mathbf{V}_{p}\left(r_{I}=\right.$ $2.75 \AA$ ) against the $\Delta \Delta H^{\mathrm{t}}$. PhX molecules used are as in Figure 2. The $\Delta \Delta H_{f}$ values are taken from that for either $\mathbf{V}_{m}$ or $\mathbf{V}_{p}$ arrangement: $\bullet$, from $\mathbf{V}_{p} ; \boldsymbol{\Delta}$, from $\mathbf{V}_{m}$.

\section{References}

[1] Holler, E., Angew. Chem. Int. Ed. Engl., 17, 648 (1978).

Dixon, M., Webb, E. C., Thorne, C. J. R. and Tipton, K. F., Enzymes, (3rd. ed.), Longman, London (1979), chap. VI.

Cramer, F. and Freist, W., Acc. Chem. Res., 20, 79 (1987).

[2] Capra, J. D. and Edmundson, A. B., Sci. American, 236, Jan. 50 (1977).

[3] Smith, H. O., Science, 205, 455 (1979).

McKnight, S. L., Sci. American, Apr. 32 (1991).

[4] Ariëns, E. J., Drug Design (Vol. I), Ed. by Ariëns, E. J., Academic Press, New York (1971), chap. 1.

[5] Lübke, K., Schillinger, E. and Töpert, M., Angew. Chem. Int. Ed. Engl., 15, 741 (1976).

[6] Cram, D. J., Angew. Chem. Int. Ed. Engl., 27, 1009 (1988).

[7] Lehn, J.-M., Angew. Chem. Int. Ed. Engl., 27, 89 (1988).

[8] Böhmer, V., Angew. Chem. Int. Ed. Engl., 34, 713 (1995).

[9] Rebek, J., Jr., Angew. Chem. Int. Ed. Engl., 29, 245 (1990).

[10] Schneider, H.-J., Angew. Chem. Int. Ed. Engl., 30, 1417 (1991). 
[11] Stoddart, J. F., Chem. Soc. Rev., 8, 85 (1979) and references cited therein.

[12] Watson, A. E. P., McLure, I. A., Bennett, J. E. and Benson, G. C., J. Phys. Chem., 69, 2753 (1965).

Zushi, S., Kodama, Y., Fukuda, Y., Nishihata, K. , Nishio, M., Hirota, M. and Uzawa, J., Bull. Chem. Soc. Jpn., 54, 2113 (1981).

Hiraki, Y. and Tai, Chem. Lett., 1982, 341.

[13] Berg, U., Liljefors, T., Roussel, C. and Sandström, J., Acc. Chem. Res., 18, 80 (1985).

[14] Lyttle, M. H., Streitwieser, A., Jr. and Kluttz, R. Q., J. Am. Chem. Soc., 103, 3232 (1981).

Carter, R. E. and Stilbs, P., J. Am. Chem. Soc., 98, 7515 (1976).

[15] Burley, S. K. and Petsko, G. A., Science, 229, 23 (1985).

[16] Burley, S. K. and Petsko, G. A., J. Am. Chem. Soc., 108, 7995 (1986).

[17] Hunter, C. A., Chem. Soc. Rev., 1994, 101 and references cited therein.

[18] Endo, T., Top. Curr. Chem., 128, 91 (1985).

[19] Endo, T., Kuwahara, A., Tasai, H., Murata, T., Hashimoto, M. and Ishigami, T., Nature, 268, 74 (1977).

[20] Endo, T., Tasai, H., Miyazawa, K., Endo, M., Kato, K., Uchida, A., Ohashi, Y. and Sasada, Y., J. Chem. Soc., Chem. Commun., 1983, 636.

[21] Ito, M. M., Kato, J., Takagi, S., Nakashiro, E., Sato, T., Yamada, Y., Saito, H., Namiki, T., Takamura, I., Wakatsuki, K., Suzuki, T. and Endo, T., J. Am. Chem. Soc., 110, 5147 (1988).

[22] Endo, T., Ito, M. M., Yamada, Y., Saito, H., Miyazawa, K. and Nishio, M., J. Chem. Soc., Chem. Commun., 1983, 1430.

[23] Endo, T., Ito, M. M. and Namiki, T., J. Chem. Soc., Chem. Commun., 1985, 933.

[24] Endo, T., Tajima, K., Yamashita, M., Ito, M. M., Nishida, J. and Ogikubo, T., J. Chem. Soc., Chem. Commun., 1986, 1561.

[25] Tsuzuki, S., Uchimaru, T. and Tanabe, K., Chem. Phys. Lett., 287, 202 (1998).

[26] Kihara, H., Uchida, N. and Ikuta, S., Bunshi Kido Ho (Molecular Orbital Method), Ed. by Osawa, E, Kodansha, Tokyo (1994), p62.

[27] Stewart, J. J. P., MOPAC93, Revision 2, Fujitsu Ltd., Nakase, Chiba, 261, Japan (1994).

[28] The $\Delta \Delta H^{\mathrm{t}}$ is the enthalpy of the weak interaction of a $\mathrm{PhX}$ molecule with the phenyl group in the stationary liquid (practically $\mathrm{PhH}$ molecule) relative to the enthalpy of that of a $n$-octane molecule with the phenyl group.

[29] Hobza, P., Selzle, H. L. and Schlag, E. W., J. Phys. Chem., 97, 3937 (1993). 
[30] Linse, P., J. Am. Chem. Soc., 115, 8793 (1993).

[31] Jorgensen, W. L. and Severance, D. L., J. Am. Chem. Soc., 112, 4768 (1990).

[32] $\mathrm{d}_{c b-c b}=2.50\left(r_{o}\right)+1.086(\mathrm{C}-\mathrm{H}$ bond length of $\mathrm{PhH})+1.392(\mathrm{C}-\mathrm{C}$ bond length of $\mathrm{PhX})$ $=4.978 \AA$

[33] Cox, E. G., Cruickshank, D. W. J. and Smith, J. A. S., Proc. R. Soc. London A, A247, 1 (1958).

[34] Slawin, A. M. Z., Spencer, N., Stoddart, J. F. and Williams, D. J., J. Chem. Soc., Chem. Commun., 1987, 1070.

[35] Steed, J. M., Dixon, T. A. and Klemperer, W., J. Chem. Phys., 70, 4940 (1979).

[36] Laatikainen, R., Ratilainen, J., Sebastian, R. and Santa, H., J. Am. Chem. Soc., 117, 11006 (1995).

[37] Price, S. L. and Stone, A. J., J. Chem. Phys., 86, 2859 (1987).

Chipot, C., Jaffe, R., Maigret, B., Pearlman, D. A. and Kollman, P. A., J. Am. Chem. Soc., 118, 11217 (1996).

[38] An ab inito study [29] of interaction energies of the benzene dimer, however, showed that the parallel-displaced structure is slightly more stable than the above-mentioned T-shaped one by $0.88 \mathrm{kcal} \mathrm{mol}^{-1}$. Similarly, a favorable offset face-to-face $\pi$-stacked geometry is predicted using a simple model of the charge distribution in a $\pi$-system [Hunter, C. A. and Sanders, J. K. M., J. Am. Chem. Soc., 112, 5525 (1990)].

[39] It has been suggested that the interaction energy for the benzene dimer calculated with ab initio method depends significantly upon the basis set implemented and the method for electron correlation calculation applied [Hobza, P., Selzle, H. L. and Schlag, E. W., J. Phys. Chem., 100, 18790 (1996)].

[40] Slejko, F. L., Drago, R. S. and Brown, D. G., J. Am. Chem. Soc., 94, 9210 (1972).

[41] Jencks, W. P., Catalysis in Chemistry and Enzymology, McGraw-Hill, New York (1969), $\mathrm{p} 415$.

[42] Optimized intermolecular distances $\left(r_{o}\right)$ are somewhat shorter than the sum of a half of thickness of a benzene ring and van der Waals radius of an $\mathrm{H}$ atom. This might be because the $\mathrm{H}$ atom in $\mathrm{PhX}$ is located just above the centroid of the other benzene ring.

[43] The PM3 MOPAC calculations have revealed that $\mathrm{PhH}-\mathrm{PhX}$ pairs sometimes adopt irrational structures (e.g., $\mathrm{CP}$ and $\mathrm{CP}^{*}$ ) in which a pair of closest $\mathrm{H}$ atoms in the interacting benzene rings are located within the van der Waals spheres. It should be noted that these unreasonable structures are occasionally more "stable", namely, have apparently more negative heats of formation than the realistic ones. Thus, when optimized geometries and/or energetics are studied using the MOPAC program for intra- or intermolecular systems composed of two (or more) aromatic rings, one had better examine whether a non-realistic structure having such an irrationally close contact of the rings is "stabilized" or not. 


\section{半経験的分子軌道法によるベンゼン一一置換 ベンゼン間相互作用のエンタルピーの計算. GLP C で求めた実験值との関係}

遠藤 忠 ${ }^{\mathrm{a} *}$, 飯田 貴広 $^{\mathrm{a}}$, 古谷 暢英 ${ }^{\mathrm{a}}$, 山田 由美子 ${ }^{\mathrm{b}}$, 伊藤 眞人 ${ }^{\mathrm{b}}$

$a$ 青山学院大学理工学部化学科 $\bar{\top}$ 157-8572 東京都世田谷区干歳台 6-16-1 *TEL 03-5384-1111, FAX 03-5384-6200

${ }^{\mathrm{b}}$ 創価大学工学部生物工学科 $\overline{\mathrm{T}} 192-8577$ 東京都八王子市丹木町 1-236

半経験的分子軌道法を用いて、ベンゼン 2 量体およびベンゼン $(\mathrm{PhH})$ 一モノ 置換ベンゼン $(\mathrm{PhX})$ 対の生成熱を計算することにより、ベンゼン一モノ置換ベン ゼン間相互作用のエンタルピーを求めた。ベンゼン 2 量体の場合について、計算法、 初期の分子間距離 $\left(r_{I}\right)$ などを検討した。PM3 法で求めた相互作用エンタルピーと 最適化後の配置は、これまでの実験值および計算値と矛盾しない。PhH一PhX系の 初期配置としては、1 ケの平行 $(\mathbf{P})$ と4 ケの垂直配置 $\left(\mathbf{V}_{r} 、 \mathbf{V}_{p} 、 \mathbf{V}_{m}\right.$ および $\left.\mathbf{V}_{b}\right)$ ( Figure 1) を選んだ。 $\mathbf{V}_{p}$ あるいは $\mathrm{V}_{m}$ 配置の場合には (この配置では、PhXの置 換基 X に対してパラあるいはメタ位にある $\mathrm{H}$ 原子が $\mathrm{PhH}$ 分子の重心の真上に存在 する)、計算から求めた $\mathrm{PhH}$ - PhX 間相互作用エンタルピー $\left(\Delta \Delta H_{f}\right)$ は、GLPC から求めた実験值 $\left(\Delta \Delta H^{\mathrm{t}}\right)$ と良い相関関係を示し (Figure 5)、相関係数 $(\rho)$ は $0.94\left(r_{I}=2.75 \AA ̊ 丿\right)$ になった。この相関式から求めた $\Delta \Delta H^{\mathrm{t}}$ と実験值 $\Delta \Delta H^{\mathrm{t}}$ との 差は、約 $0.1 \mathrm{kcal} \mathrm{mol}^{-1}$ 以下であった。他の配置の場合には $\left(\mathbf{V}_{p}\right.$ 配置を除くと)、 $\Delta \Delta H_{f}$ と $\Delta \Delta H^{\mathrm{t}}$ との間に相関関係は認められなかった。

キーワード : Intermolecular interaction, Aromatic-aromatic interaction, Benzenemonosubstituted benzene, MOPAC93, Relationship between calculated and experimental interaction enthalpies 